Rita Kusumawati

${ }^{1}$ Prodi M anajemen, Fakultas E konomi

dan Bisnis, U niversitas M uhammadiyah

Yogyakarta

Jalan B rawijaya, Tamantirto, K asihan,

B antul, Yogyakarta 55163

1E mail: kusumawatirita@yahoo.com

\section{Pendampingan Pengolahan Ubi Ungu Berbasis Value Added Method}

https:/ / doi.org/ 10.18196/ bdr.428

\begin{abstract}
ABSTRAK
Program ini bertujuan membantu petani ubi ungu di daerah Sanden Bantul untuk meningkatkan kesejahteraannya melalui peningkatan nilai (value added) hasil pertanian mereka. Peningkatan nilai dilakukan dengan cara mengolah ubi menjadi tepung, kemudian diolah menjadi makanan ringan, produk dikemas dengan baik dan menarik sehingga bisa dipasarkan di toko toko/supermarket dan dengan pemasaran via internet. Metode yang digunakan adalah: pelatihan pembuatan tepung ubi ungu, pelatihan manajemen usaha dan pemasaran tepung ubi ungu, pelatihan pembuatan Inovasi Produk Stik Ubi Ungu, pelatihan pemasaran produk stik Ubi Ungu. Hasil dari program ini adalah masyarakat antusias dalam mengikuti rangkaian pelatihan yang diadakan, terlihat dari peserta yang hadir disetiap kegiatan pelatihan. Dari kegiatan pelatihan tersebut muncul kelompok unit usaha pengolahan ubi ungu menjadi tepung dengan merk "Olet" dan kelompok usaha makanan ringan dengan merk "Stik Echo' Kata kunci: pengolahan ubi ungu, value added
\end{abstract}

\title{
PENDAHULUAN
}

Kecamatan Sanden merupakan salah satu kecamatan yang terdapat di Kabupaten Bantul Yogyakarta. Kecamatan Sanden terletak disebelah barat dari I bukota Kabupaten Bantul serta memiliki luas daerah 2.315,9490 hektar yang terdiri dari empat desa yaitu desa Gadingharjo, Srigading, Murtigading dan Gadingsari. Kecamatan Sanden yang berada didataran rendah daerah tropismenyebabkan suhu tertinggi dapat mencapai $32^{\circ}$ $\mathrm{C}$ dan suhu terendah $23^{\circ} \mathrm{C}$. Daerah ini dihuni oleh $7.028 \mathrm{Kepala} \mathrm{Keluarga,} \mathrm{dengan}$ jumlah penduduk keseluruhan sebanyak ý33.968 orang. Berdasarkan jenis kelamin, penduduk Kecamatan Pajangan terdiri dari 14.565 penduduk laki-laki dan 15.452 penduduk perempuan. Kepadatan penduduk di Kecamatan Sanden adalah 903 jiwa/ $\mathrm{km}^{2}$. M ata pencaharian penduduk Kecamatan Sanden sebagian besar adalah petani. 
D ata M onografi Kecamatan Sanden menyebutkan 12.541 orang atau 41,7 \% dari seluruh penduduk Kecamatan Sanden bekerja di sektor pertanian.

D esa Gadingharjo yang merupakan bagian dari kecamatan Sanden memiliki empat dusun yaitu dusun Karanganyar, dusun Pranti, dusun Daleman dan dusun Ngujung. Pedukuhan Karanganyar memiliki 5 RT yang masing-masing jumlah setiap RT berbedabeda. Berdasar data statistic, jumlah penduduk Karanganyar adalah \pm 500 jiwa dengan 361 kepala keluarga dan berdasarkan jenis kelaminnya jumlah penduduk Karanganyar yang berkelamin laki-laki berjumlah 200 jiwa dan penduduk yang berkelamin perempuan berjumlah 300 jiwa. Pendidikan warga dukuh Karanganyar paling tinggi ada pada tingkatan SD, SM P, SM A, S1 dan S2.

M ayoritas mata pencaharian pedukuhan Karanganyar adalah dari sektor pertanian. Selain menanam padi, warga di pedukuhan Karanganyar banyak melakukan budidaya ubi jalar. Selama ini ubi jalar dijual oleh petani dalam bentuk mentahan dengan harga jual produk yang rendah bahkan kadangkala tidak mampu menutupi biaya yang dikeluarkan, sehingga seringkali petani mengalami kerugian. Kondisi tersebut yang pada akhirnya menyebabkan rendahnya tingkat kesejahteraan petani. Rendahnya tingkat kesejahteraan petani dikarenakan rendahnya nilai tambah produk yang dinikmati petani. Petani menjual produk panen begitu saja sementara proses lainnya seperti pengolahan, penjualan dilakukan oleh pihak yang lainnya. Nilai tambah (value added) merupakan pertambahan nilai suatu komoditas karena men galami proses pengolahan, pengangkutan ataupun penyimpanan dalam suatu produksi (Hamidah M, dkk, 2015). Dalam proses pengolahan, nilai tambah merupakan selisih antara nilai produk dengan biaya biaya yang dikeluarkan seperti biaya bahan baku dan input lainnya, tidak termasuk tenaga kerja (H ayami et.al,1987). Sumber nilai tambah terbesar bagi produk pertanian adalah pada pengolahan dan kegiatan penjualan/ pemasaran (Awaludin, 2014).

Potensi pengembangan produk olahan ubi jalar dusun Karanganyar sangat tinggi mengingat banyaknya petani yang melakukan budidaya ubi jalar. Tepung ubi ungu memiliki komposisi: kadar air $7 \%$, protein $3 \%$, lemak 0,5\%, serat kasar $2 \%$, abu $2 \%$ dan pati $60 \%$. Karena kandungannya tersebut, tepung ubi bisa menjadi produk substitusi tepung terigu untuk industri makanan olehan (Koswara, S, 2013). Prospek permintaan terhadap tepung ubi ungu kedepan diperkirakan juga semakin baik, karena semakin banyaknya orang yang peduli terhadap pola hidup sehat dengan mengurangi konsumsi bahan makanan dengan kandungan gula yang tinggi. Kendalanya adalah masyarakat dusun Karanganyar masih kekurangan pengetahuan mengenai pengolahan produk olahan 


\section{5}

ubi jalar, dan juga masih rendah pemahaman dalam pemasaran produk.

Berdasarkan permasalahan yang dihadapi warga Karanganyar Sanden, maka program ini fokus pada peningkatan nilai produk ubi ungu yang diharapkan akan meningkatkan kesejahteraan petani setempat. Peningkatan nilai difokuskan melalui kegiatan (1). Pengolahan ubi menjadi tepung; (2) Manajemen usaha dan marketing produk tepung' (3) Peizinan Pangan Industri Rumah Tangga (PIRT); (4).Pembuatan inovasi produk stik ubi ungu; (5).Pemasaran produk stik ubi ungu.

\section{METODE PELAKSANAAN}

D alam pelaksanaan program peningkatan nilai produk ubi ungu yang dihasilkan petani tersebut akan dilakukan beberapa tahapan, yaitu:

\section{Pelatihan pembuatan tepung ubi ungu}

Pelatihan pembuatan tepung ubi ungu dilakukan dengan menghadirkan narasumber yangtelah mempunyai pengalaman membuat tepung ubi ungu. Proses pelatihan dilakukan dengan beberapatahap, yaitu membuat video tentang pembuatan ubi ungu, tahap kedua memberikan penyuluhan pembuatan tepungubi ungu, dan tahap terakhir adalah praktik pembuatan tepung ubi ungu.

\section{Penyuluhan manajemen usaha dan pemasaran tepung ubi ungu.}

Penyuluhan manajemen usaha dilakukan dengan mengundang narasumber dari dosen M anajemen U MY yang akan memberikan materi tentang bagaimana mengelola usaha dengan baik termasuk diantaranya strategi pemasaran produk tepung ubi ungu.

\section{Penyuluhan perijinan PIRT(Pangan Industri Rumah Tangga).}

Iżn Pangan Industri Rumah Tangga (PIRT) merupakan ijin yang dikeluarkan oleh D epartemen Kesehatan RI berdasarkan syarat syarat tertentu terhadap makanan olahan yang dihasilkan oleh industri rumah tangga. PIRT ini sangat penting bagi sebuah industri rumah tangga, karena dengan adanya PIRT berarti produk makanan tersebut sudah legal dipasarkan dan konsumen merasa yakin akan produk yang dikonsumsi. PIRT ini merupakan salah satu unsur penting dalam pemasaran suatu produk makanan (Sani A, 2015).

Program penyuluhan PIRT dilakukan dengan menghadirkan narasumber dari Dinas Kesehatan Bantul. 


\section{Pelatihan pembuatan Inovasi Produk Stik U bi Ungu,}

Program inovasi produk pembuatan stik ubi dilakukan dalam tiga tahap.

Tahap Pertama : Proses eksperimen atau percobaan pembuatan stik. T

Tahap kedua : M elakukan koordinasi dengan ibu-ibu kader PKK dan juga Kelompok ibu-ibu pembuat makanan pesanan..

Tahap ketiga : Demo pembuatan produk stik ubi ungu.

\section{Pelatihan produksi dan pemasaran produk Stik U bi U ngu}

Program Produksi dan Pemasaran Produk Stik U bi "EnukE cho"dibagi menjadi tiga tahap.

Tahap pertama : Proses produksi awal yang dilakukan tim dengan kelompok usaha dan ibu-ibu kader PKK.

Tahap kedua: : Pembuatan merk(brand) produk stik ubi tersebut.

Tahap ketiga : Pemasaran produk.

\section{HASIL DAN PEMBAHASAN}

1. Pelatihan Pembuatan tepung Ubi Ungu

Pelatihan pembuatan tepung ubi ungu dilaksanakan pada tanggal 25 A gustus 2016 pukul 09.30 WIB dan penyuluhan Manajemen pemasaran dilaksanakan pada tanggal 31 A gustus 2016 pukul 14.00 W IB dengan narasumber ibu Sumarmiyati. I bu Sumarmi yati adalah adalah salah satu produsen tepung ubi ungu. Tim membuat video profil narasumber dan video tutorial pembuatan tepungubi jalar ungu. Tim melakukan praktek membuat tepung ubi jalar ungu untuk merealisasikan teori pembuatan tepungubi jalar yang ada. Pelatihan pembuatan tepungubi ungu dihadiri oleh sekitar 30 warga kelompok ibu ibu tani

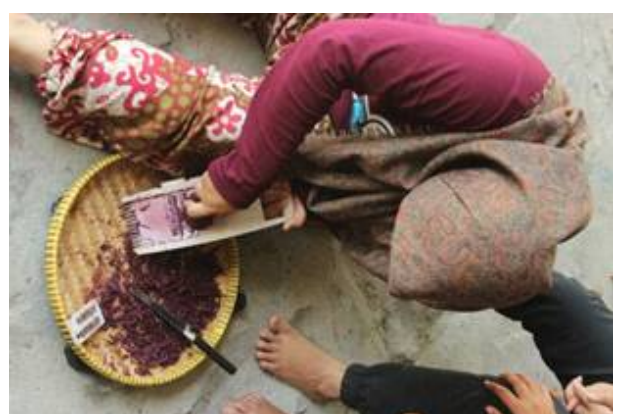

Gambar 1: Proses pemarutan ubi

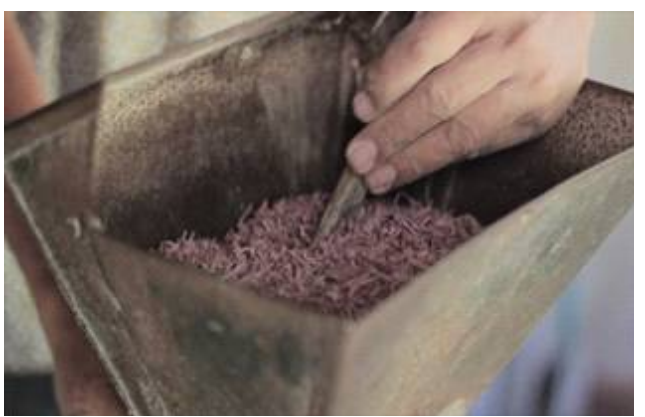

Gambar 2: Proses Penggilingan 


\section{Penyuluhan Manajemen Usaha dan Marketing Produk .}

Pelatihan manajemen usaha dan pemasaran produk dilaksanakan pada tanggal 31 A gustus 2016 dengan den gan narasumber ibu Rita Kusumawati S.E, M .Si. A cara dihadiri oleh sekitar 21 warga yang terdiri dari bapak bapak dan ibu ibu kelompok tani Karanganyar. $M$ ateri penyuluhan difokuskan pada pentingnya manajemen usaha dan strategi pemasaran dalam keberhasilan sebuah usaha. Strategi pemasaran difokuskan pada kemasan produk dan promosi serta sistem penjualan.W arga sekitar san gat antusias mengikuti penyuluhan ini. Setelah mengikuti penyuluhan, tim beserta kelompok tani menentukan merk tepung ubi ungu yang dihasilkan dan membuat disain kemasan. M erk tepung ubi ungu dusun Karanganyar adalah Tepung U bi U ngu "O LET"

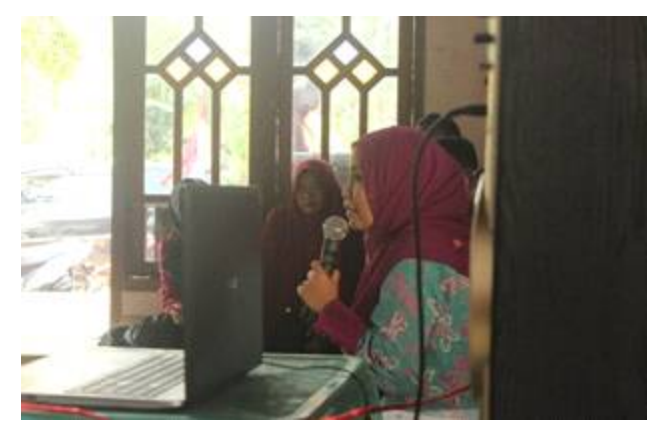

Gambar 3: Penyuluhan manajemen usaha

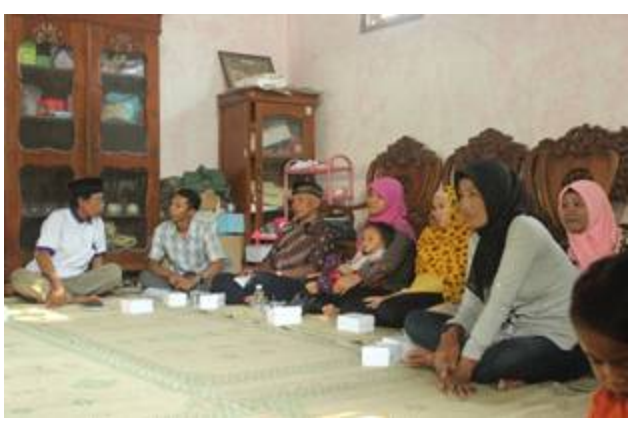

Gambar 4: Peserta penyuluhan manajemen usaha

3. Program Sosialisasi Pra-Perizinan Pangan Industri Rumah Tangga (PIRT)

D usun Karanganyar sendiri memiliki banyak potensi untuk membuka usaha produksi pangan. D alam program pokok KKN tematik U M Y kelompok 44 pun juga memberikan tambahan opsi rintisan usaha bagi warga Dusun Karanganyar, yaitu produksi stik ubi "Enuk Echo" Karanganyar. Dengan adanya usaha produksi pangan tersebut, tentu masyarakat Dusun Karanganyar perlu memiliki pemahaman mengenai izin Pangan Industri Rumah Tangga (PIRT) yang mana sangatlah penting untuk tindak lanjut pemasaran produk pangan yang dihasilkan. Berangkat dari hal tersebut KKN tematik U M Y kelompok 44 melihat bahwa masyarakat D usun Karanganyar merasa memerlukan sosialisasi tentang informasi terkait pra-perizinan PIRT dari Dinas Kesehatan sebagai instansi pemerintah yang mengurusi tentangperizinan PIRT tersebut. O leh karena itu, KKN tematik U M Y kelompok 44 beserta masyarakat D usun Karanganyar merumuskan program kerja pokok KKN berupa Sosialisasi Pra.Perizinan Pangan Industri Rumah Tangga (PIRT).

Kegiatan dilaksanakan pada:Selasa, 40 ktober 2016, jam $13.00-16.00$ WIB , bertempat di Rumah Kepala Dusun Karanganyar (Bapak Trisno Atmojo) JI. 
Kromoinangun, Karanganyar, Gadingharjo, Sanden, Bantul. Kegiatan diikuti oleh kelompok tani Karangrejo yang merupakan kelompok tani di D usun Karanganyar selain itu kaderkader PKK D usun Karanganyar dan jugaKelompok ibu-ibu pembuat makanan ringan dari hasil pertanian mereka. Kegiatan ini dihadiri oleh 19 orang warga D usun Karanganyar dari 26 undangan. Ibu Nelly dari Dinas Kesehatan Kabupaten Bantul bertindak sebagai narasumber.

\section{Program Penyul uhan Pembuatan Inovasi Produk Stik Ubi Enuk-Echo Karanganyar.}

Program inovasi produk pembuatan stik ubi ditujukan untuk meningkatkan nilai ekonomi komoditas hasil pertanian terutama ubi jalar dan meningkatkan daya saing pertanian warga D usun Karanganyar. Kegiatan ini dilakukan pada hari Kamis, 29 September 2016, bertempat di rumah kepala dusun Karanganyar JI. Kromoinangun, Karanganyar, Gadingharjo, Sanden, Bantul; dan diikuti oleh ibu-ibu kader PKK D usun Karanganyar dan juga Kelompok ibu-ibu pembuat makanan pesanan D usun Karanganyar.

Pelaksanaan program dilakukan dengan tiga tahap. Pertama yaitu proses eksperimen atau percobaan pembuatan stik. Dalam tahap ini penanggungjawab program dan rekanrekan tim KKN 44 U MY melakukan percobaan pembuatan stik ubi dari ubi jalar dan juga tepung OLET. Proses atau tahap percobaan dilakukan dengan tujuan untuk mendapatkan adonan yang baik, seperti adonan tidak bantet, adonan tidak gampang gosong dan percobaan pembuatan varian rasa stik. Tahap kedua adalah melakukan koordinasi dengan ibu-ibu kader PKK dan juga Kelompok ibu-ibu pembuat makanan pesanan.Koordinasi bertujuan untuk mengundang ibu-ibu dalam acara penyuluhan dan juga kesediaannya untuk meminjamkan alat produksi.

Tahap terakhir adalah eksekusi program yaitu penyuluhan, dalam tahap ini tim penanggungjawab program melakukan demo masak pembuatan stik ubi kepada tamu undangan. D emo masak ini bertujuan untuk memberikan informasi tahap-tahap proses pembuatan stik ubi kepada ibu-ibu undangan. Tamu undangan juga diberi kesempatan untuk melakukan sendiri praktek memasak seperti, membuat adonan, memotong dan juga menggoren $\mathrm{H} . \mathrm{H}$ al ini diharapkan agar ibu-ibu dapat secara langsung mempraktekkan dan dapat membuat stik tersebut setelah pelatihan selesai. Penyuluhan program inovasi pembuatan stik ubi berjalan dengan baik dari semua kader PKK dan kelompok usaha semuahadir terkecuali kader PKK RT 01 hal ini dikarenakan ibu kader PKK RT 01 sedang mempunyai hajat. Penanggung jawab program berhasil mendorong dan berbagi informasi perihal pembuatan stik ubi dan tamu undangan juga antusisas dalam program 
ini. Dari program ini yang harus dievaluasi adalah perihal antusias warga untuk terus berinovasi karena warga hanya akan anstusias jika ada yang memberikan arahan dan belum mampu mencanangkan program sendiri karena pada dasarnya kelompok usaha dan ibu PKK mempunyai kemampuan akan inovasi tetapi belum ada dorongan dan sadar akan kemampuan tersebut.

\section{Program Produksi dan Pemasaran Produk Stik Ubi "Enuk-Echo" Karanganyar}

Permasalahan dari warga Dusun Karanganyar tidak hanya berhenti pada tahapan inovasi produk untuk meningkatkan nilai ekonomi komoditas pertanian mereka akan tetapi lebih lanjut lagi yaitu proses produksi yang masih terkendala keterbatasan alat dan sumberdaya manusia dan juga proses pemasaran yang terkendala karena tidak adanya segmentasi pasar yang jelas. $\mathrm{H}$ al ini men dorong tim untuk melakukan koordinasi dengan ibu-ibu kader PKK dan juga Kelompok U saha M akanan untuk bersinergi agar produk stik ubi dapat dilanjutkan dan ditindak lanjuti sebagi produk olahan asli Karanganyar.

Sinergi antara ibu-ibu kader PKK dan ibu-ibu Kelompok U saha makanan pesanan juga dapat mengatasi permasalahan mereka yaitu keterbatasan alat dan kekurangan sumberdaya manusia. Karena ketika mereka bersinergi dan berkoordinasi alat akan lebih banyak karena dari dua kelompok yang berbeda mempunyai alat masing masing dan jika digabungkan dapat membuat produksi dalam skala besar. Ditambahlagi sinergi kedua kelompok akan memberbanyak sumberdaya manusia untuk melakukan proses produksi. Sedangkan untuk proses pemasaran tim berkoordinasi dengan toko maupun pusat oleholeh dan pasar di sekitar D usun Karanganyar maupun diluar D usun Karan ganyar untuk menitipkan Stik U bi tersebut.

Program Produksi dan Pemasaran Produk Stik U bi "Enuk-Echo"dibagi menjadi tiga tahap. Pertama yaitu proses produksi tim KKN 44 U M Y dengan kelompok usaha dan ibu-ibu kader PKK. Proses produksi ini ditujukan untuk mendorong masyarakat agar langsung men gimplementasi kan penyuluhan yang mereka telah dapatkan sehingga mereka dapat memperoleh output dari program yang dilakukan oleh tim KKN 44 U M Y. Proses produksi dilakukan dari tahap memasak hingga pengemasan produk. Tahap selanjutnya adalah pembuatan brand dari produk stik ubi tersebut. Penentuan brand produk ditentukan dari hasil koordinasi danmusyawarah antara tim KKN 44 UMY dengan kelompok terkait. $\mathrm{H}$ al ini menghasilkan produk bernama Stik U bi Enuk-Echo Karanganyar. Tahap terakhir adalah pemasaran produk, dalam proses ataupun tahapan pemasaran tim KKN dan ibu-ibu kelompok terkait dibagi menjadi beberapa kelompok 
untuk melakukan pemasaran kebeberapa toko maupun pusat oleh-oleh di sekitar D usun Karanganyar dan diluar D usun Karanganyar. Kegiatan dilaksanakan pada hari tanggal 9 O ktober sampai dengan 120 ktober 2016 bertempat di Posko KKN Tematik 44 U niversitas M uhammadiyah YogyakartaJI. Kromodiryo dusun Karanganyar G adingharjo Sanden Bantul. Sasaran program produksi dan pemasaran Stik U bi Enuk-Echo Karanganyar adalah ibu-ibu kader PKK Dusun Karanganyar dan juga Kelompok ibu-ibu pembuat makanan pesanan D usun Karanganyar.

Program Produksi dan Pemasaran Stick U bi Enuk-Echo berjalan dengan baik tim dan Kelompok U saha yang diketuai oleh Ibu Saminah berhasil melakukan produksi dan pemasaran produk. Tim dan Kelompok U saha mampu melakukan produksi sejumlah 78 kemasan besar dan 44 kemasan kecil, selain itu pada proses pemasaran konsumen juga merespon dengan baik hal ini dibuktikan Bupati Bantul Bapak. Drs. Suharsono juga membeli produk tersebut.

Kegiatan Produksi dan Pemasaran Stick Ubi "Enuk Echo" Karanganyar

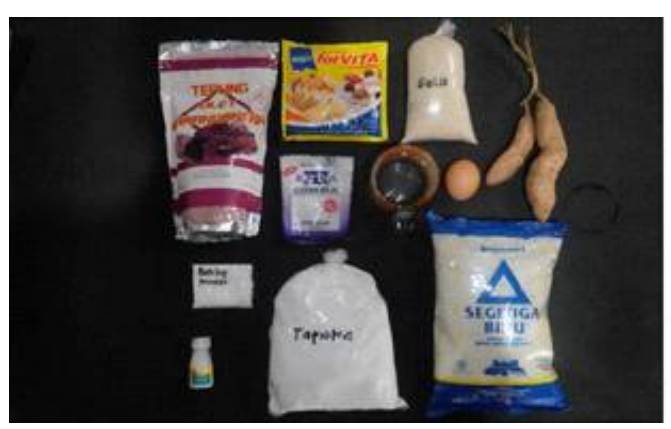

Gambar 5. Bahan-bahan stick ubi "Enuk Echo"

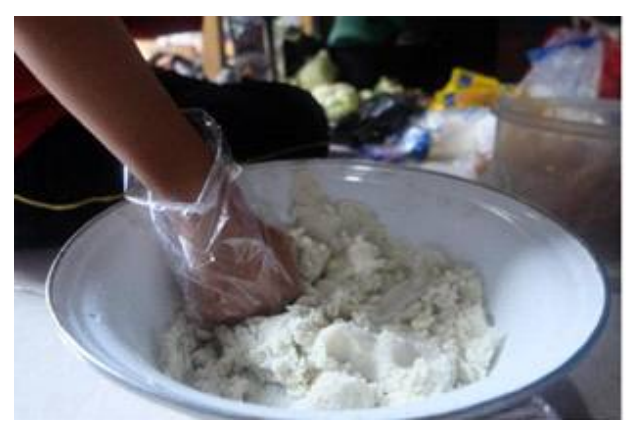

Gambar 7.Proses penghalusan ubi

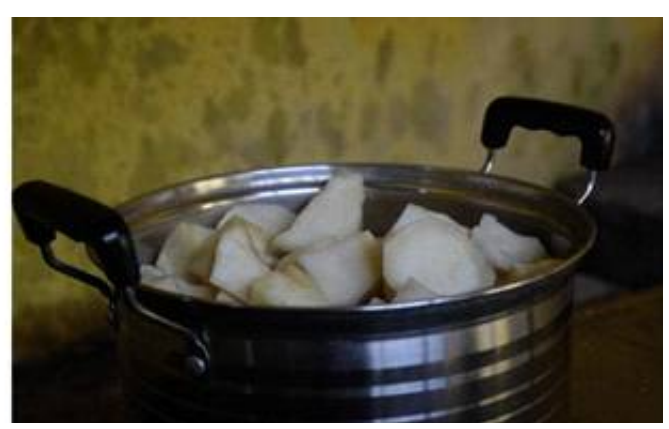

Gambar 6. Proses pengukusan ubi

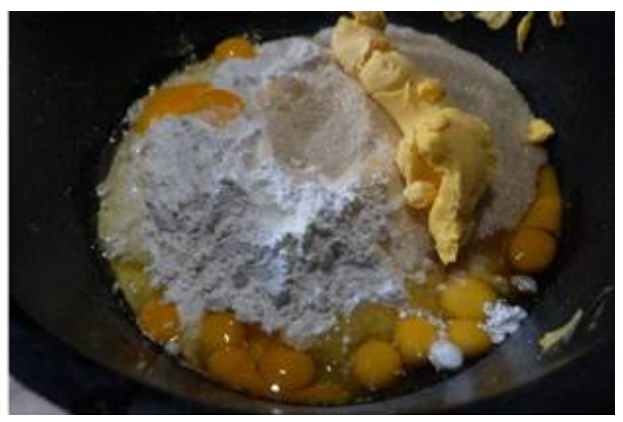

Gambar 8. Proses pencampuran seluruh bahan 


\section{1}

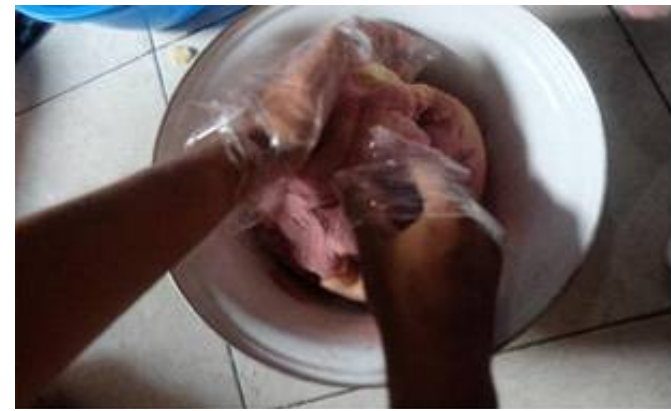

Gambar 9.ubi ungu sedang diuleni.

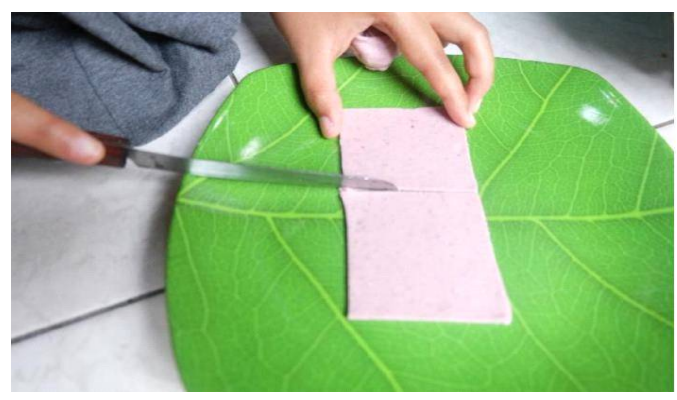

Gambar 11. Adonan yang ditipiskan dipotong tepiannya Gambar 12 Adonan yang telah dipotong kecil-kecil

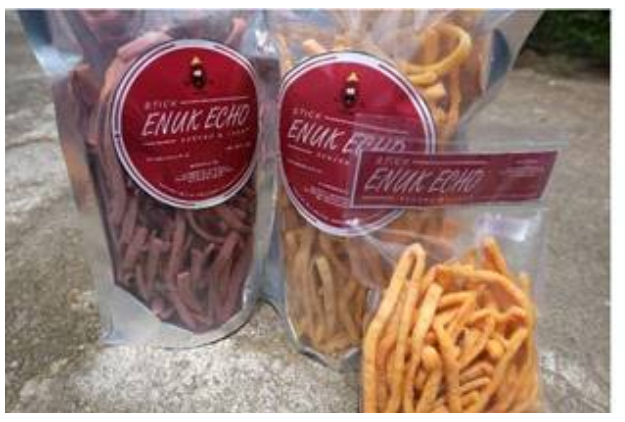

Gambar13. Stick ubi siap untuk dipasarkan

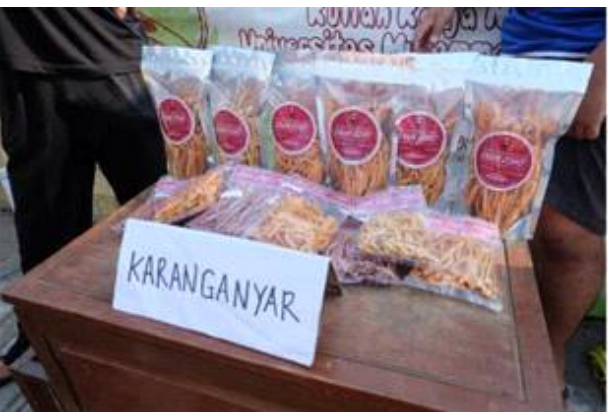

Gambar 13. Stand pemasaran stick ubi "Enuk Echo"
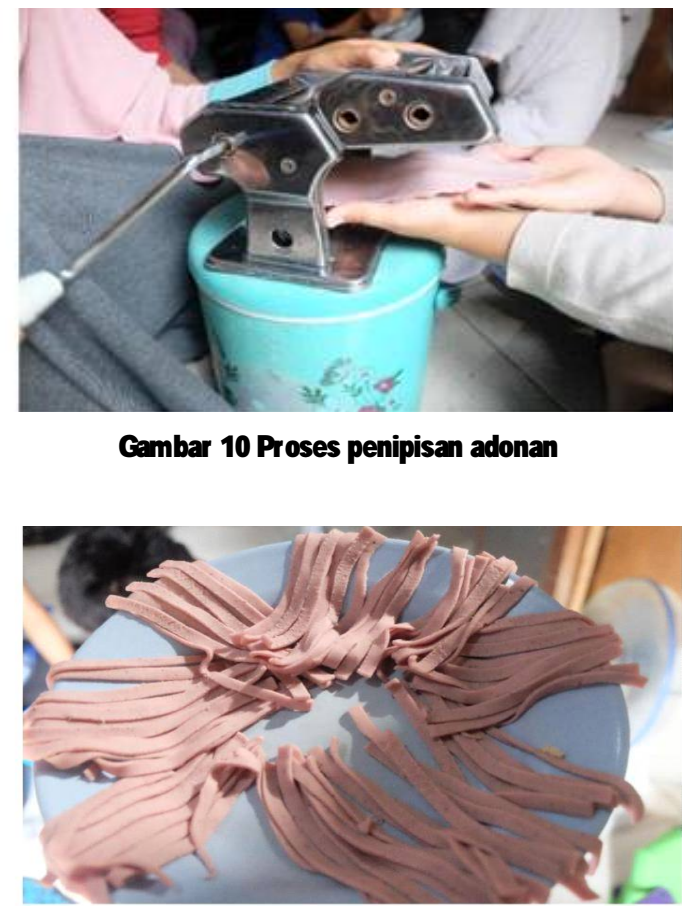

Gambar 10 Proses penipisan adonan

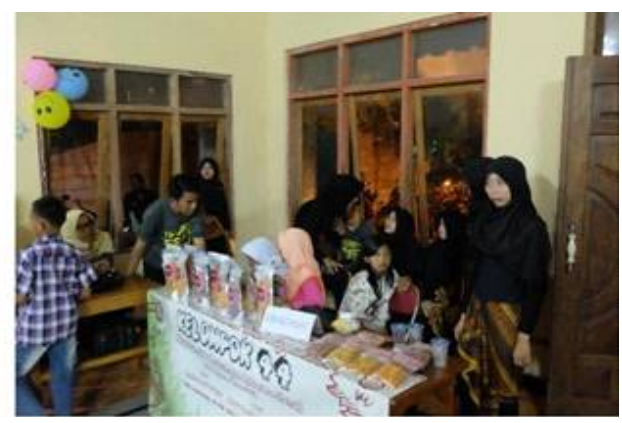

Gambar 14. Stand pemasaran stick ubi

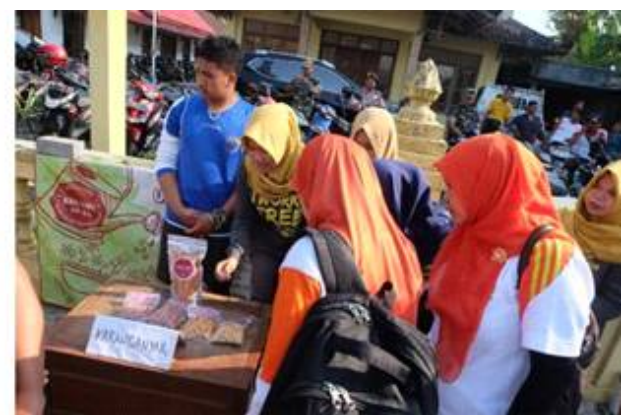

Gambar 14. Kegiatan pemasaran stick ubi 


\section{PEMASARAN STICK UBI "ENUK ECHO" KARANGANYAR MELALUI SOCIAL MEDIA}

\section{Facebook}

Nama akun: Stick Enuk Echo

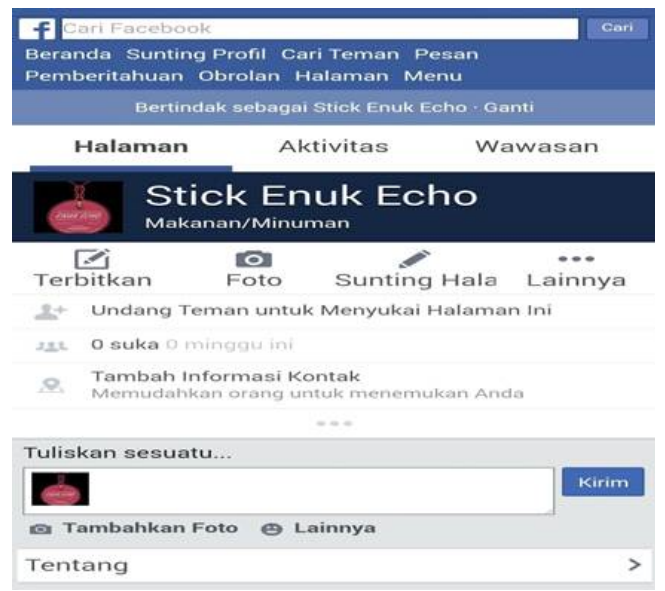

\section{Instagram}

Nama akun: stickenukecho

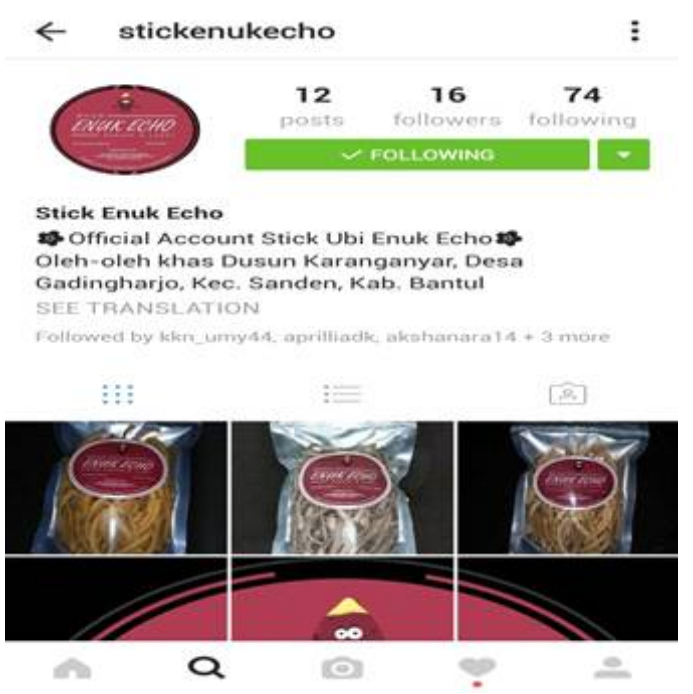

\section{SIMPULAN}

Berdasarkan program yang sudah dilaksanakan semuanya berjalan dengan baik dan mampu membuka wawasan petani di daerah Sanden Bantul dalam rangka meningkatkan nilai hasil tani mereka.

M asyarakat Sanden memiliki tambahan ketrampilan dalam pen golahan ubi ungu dan pemasarannya. M asyarakat membentuk 2 kelompok yaitu kelompok pembuat tepung ubi yang produknya diberi merk tepung ubi ungu "O LET: dan kelompok pembuat olahan 
tepung stik ubi ungu dengan merk "Stik ubi ungu Enuk Echo". Selain itu, masyarakat dibekali dengan pengetahuan PIRT sehingga usaha masyarakatt legal. Program pengabdian ini dapat meningkatkan perekonomian kesejahteraan petani Sanden.

\section{SARAN}

D ari semua program yang telah dijalankan diajukan saran saran sebagai berikut:

1. A tensi masyarakat akan pengolahan ubi ungu ini perlu ditingkatkan

2. M asih perlunya dilakukan upaya pemerintah setempat untuk membantu pemasaran produk olahan ubi ungu

\section{UCAPAN TERIMAKASIH}

Pada kesempatan ini kami menyampaikan terimakasih kepada

1. Pemerintah desa Sanden Bantul

2. Kepala dusun Karanganyar Sanden Bantul

3. Ketua kelompok tani dusun Karanganyar Sanden Bantul.

4. Tim KKN U MY 44 Sanden Bantul

5. Tim KKN UMY 154

\section{DAFTAR PUSTAKA}

Awaludin Rohadi, Dr, 2014. Meningkatkan Kesejahteraan Petani dengan Meraih Nilai Tambah, https://berandainovasi.com/ meningkatkan-kesejahteraan-petani-denganmeraih-nilai-tambah/
Hamidah M, Hamid A, Sudrajat J, 2015, Analisis Nilai Tambah Agroindustri Kripik Ubi di Kota Pontianak, Journal Social Economics of Agriculture 